University of Wollongong

Research Online

Faculty of Engineering - Papers (Archive)

Faculty of Engineering and Information

Sciences

22-2-2007

\title{
Analysis of Radial Vacuum-Assisted Consolidation Using 3D Finite Element Method
}

Cholachat Rujikiatkamjorn

University of Wollongong, cholacha@uow.edu.au

Buddhima Indraratna

University of Wollongong, indra@uow.edu.au

Follow this and additional works at: https://ro.uow.edu.au/engpapers

Part of the Engineering Commons

https://ro.uow.edu.au/engpapers/335

\section{Recommended Citation}

Rujikiatkamjorn, Cholachat and Indraratna, Buddhima: Analysis of Radial Vacuum-Assisted Consolidation Using 3D Finite Element Method 2007.

https://ro.uow.edu.au/engpapers/335

Research Online is the open access institutional repository for the University of Wollongong. For further information contact the UOW Library: research-pubs@uow.edu.au 


\title{
Analysis of Radial Vacuum-Assisted Consolidation Using 3D Finite Element Method
}

\author{
Cholachat Rujikiatkamjorn $^{1}$ and Buddhima Indraratna ${ }^{2}$ \\ ${ }^{1}$ Research Associate, School of Civil, Mining and Environmental Engineering, \\ University of Wollongong, NSW 2522, Australia \\ ${ }^{2}$ Professor of Civil Engineering, School of Civil, Mining and Environmental \\ Engineering, University of Wollongong, Wollongong City, NSW 2522, Australia. PH: \\ (61-2)-4221 3046; FAX: (61-2)-4221 3238; email: indra@uow.edu.au
}

\begin{abstract}
In this study, a 3D numerical modelling of a single vertical drains consolidation incorporating vacuum preloading considering both vertical and horizontal drainage is presented. The effects of nonlinear soil compressibility, varying permeability and vacuum pressure distribution along the drain are examined through the dissipation of average excess pore pressure and associated settlement. A selected case history, using 3D finite element method, is employed to analyse two embankments constructed at the Second Bangkok International Airport, Thailand stabilised with prefabricated vertical drains and vacuum preloading. The behaviour of this embankment including settlements and excess pore pressures is then compared with the numerical predictions. This study reveals a close agreement between the predictions results obtained from the numerical model and the field measurements.
\end{abstract}

\section{INTRODUCTION}

In recent years, a system of vacuum-assisted preloading via prefabricated vertical drains (PVDs) has become the most popular methods of soft ground improvement (Indraratna and $\mathrm{Chu}, 2005$ ). The utilisation of geosynthetic prefabricated vertical band drains to reduce the drainage path has become an economical and viable option due to its rapid installation (Bo et al.,2003). The implementation of vacuum application via PVDs is cost-effective, and the height of the surcharge embankment can be reduced to avoid embankments stability issue (Shang et al., 1998). The vacuum pressure increases the 
radial hydraulic gradient of soil surrounding PVDs, thereby increasing the consolidation rate.

In order to analyse the behaviour of radial consolidation of soft soils, the unit cell theories and the equivalent plane strain (2D) numerical modeling have been employed to design and predict the soil behaviour (Barron, 1948; Hansbo, 1981; Hird et al., 1992; Indraratna and Redana, 2000). In the analysis, the vertical band drain and its influence zone has to be assumed in the analytical solution (Fig.1a). Either unit cell geometry or permeability in 2D analysis has to be made equivalent to obtain the same consolidation response (Fig. 1b). However, the discrepancy between the measured and predicted consolidation based on the approximate 2D modelling techniques can be found from previous studies (Hird et al. 1992). Borges (2004) described the advantages of 3D FEM for vertical drains.

In this paper, a three dimenasional analysis was applied to two embankments at the Second Bangkok International Airport, Thailand using a finite element code (ABAQUS, Hibbitt, et al., 2004). In the numerical analysis, the actual band drains crosssection, influence zone, the parabolic permeability variation in the smear zone and the time-dependent vacuum pressure are considered. Subsequently, the 3D numerical results are compared to the field observations.

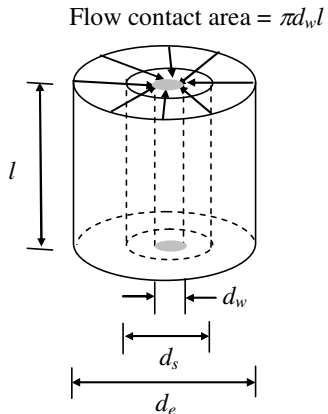

(a)

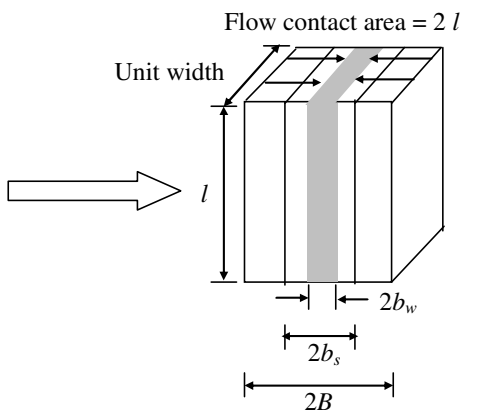

(b)

Figure 1. Unit cell analysis: (a) axisymmetric condition, (b) equivalent plane strain condition (after Indraratna et al., 2005)

\section{DESCRIPTIONS OF THE CASE HISTORIES}

As part of the Second Bangkok International Airport, Thailand, a series of test embankments was constructed to assess the performance of PVDs improved subsoil. Embankments TV1 and TV2, were built with PVDs and vacuum application. Figure 2 
shows the plan view for both embankments. The embankment characteristics and subsoil profiles at this site were explained elsewhere by Indraratna et al. (2004). In brief, 15m and 12m long PVDs were installed under TV1 and TV2, respectively. The sand blanket (working platform) was constructed with sand $0.3 \mathrm{~m}$ and $0.8 \mathrm{~m}$ for embankments TV1 and TV2, respectively with an air and water tight membrane placed on top of the drainage system.

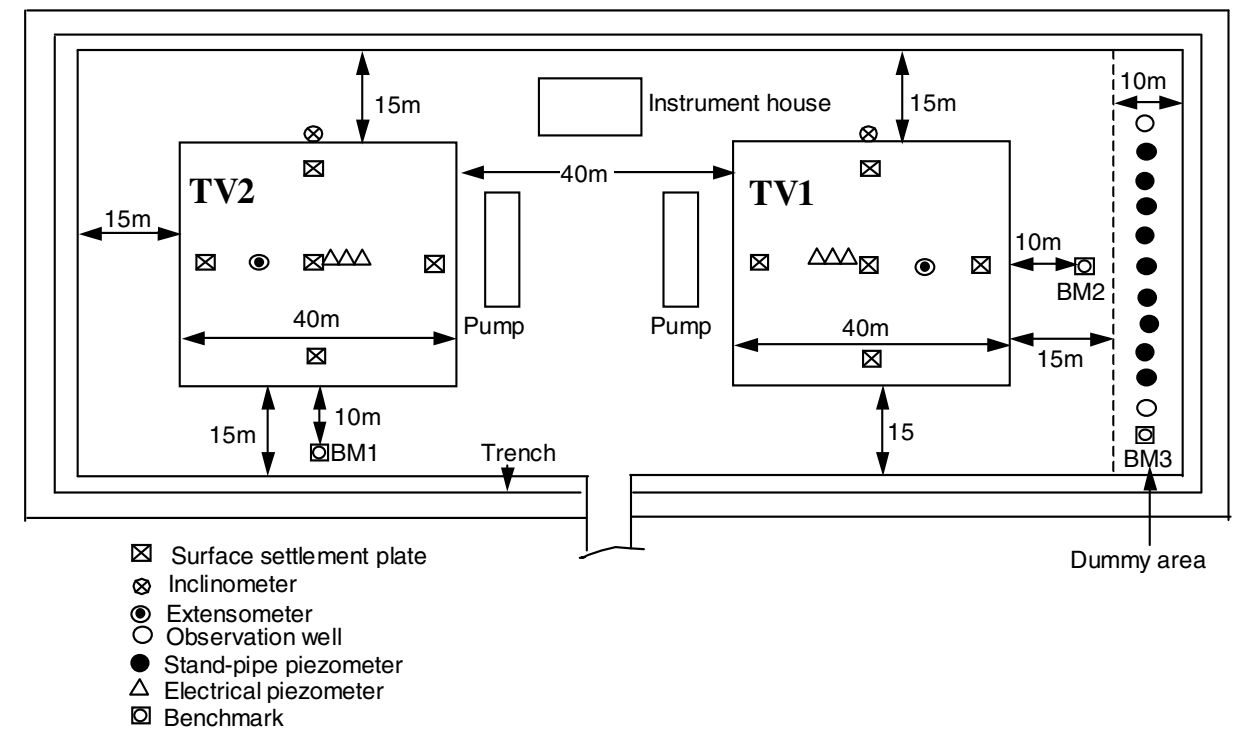

Figure 2. Site plan for the test embankments at Second Bangkok International Airport (after Sangmala, 1997)

\section{NUMERICAL MODELING OF VERTICAL DRAIN INCORPORATING VACUUM PRELOADING}

A 3D finite element program (ABAQUS) was used to simulate a unit cell with a band shape vertical drain. The total of 2000 eight-node tri-linear displacement nodes with 8 pore pressure nodes (C3D8P) were employed (Fig. 3a). In each element, there are 8 degrees of freedom for displacement and 8 degrees of freedom for pore pressure.

The dimensions of the unit cell (see Fig. 3b) were $1 \mathrm{~m}$ (drain spacing) and $15 \mathrm{~m}$ (height). The condition of zero lateral displacement in accordance with the 1-D consolidation were assumed. The drain elements is modeled by elastic properties $(E=1$ $\mathrm{MPa}, v=0.25$ ), while the remaining outer soil elements are made to obey the modified Cam-clay model. These values of elastic modulus and the Poisson's ratio were selected so that they are in the range of typical clay soil used in this study (Indraratna et al., 2004). The top, bottom and outer boundaries were set as impermeable. Only one-fourth of the influence area was used in the model because of the two axes of symmetry. The 5 
layers subsoil properties for Modified Cam-Clay model obtained from triaixial and standard oedometer tests are summarized in Table 1 (Indraratna et al., 2005b).

Many researchers (e.g. Onoue et al., 1991; Indraratna and Redana, 1998; Sharma and Xiao, 2000; Sathananthan and Indraratna, 2006; Walker and Indraratna, 2006) observed that the disturbance in the 'smear zone' increases towards the drain (Fig. 4). The parabolic decay of permeability proposed by Walker and Indraratna (2006) was incorporated in the analysis to represent more realistic smear zone.

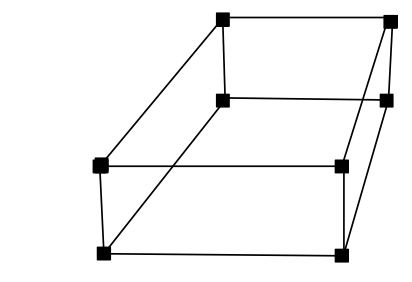

- Displacement and pore pressure node

(a)

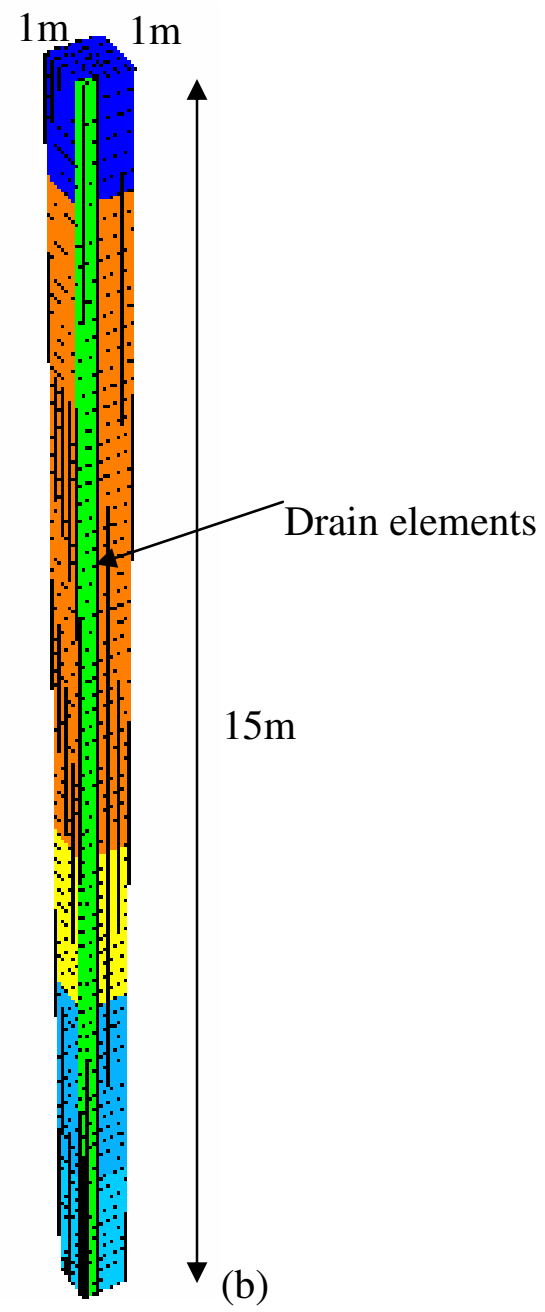

Figure 3 Finite element discretization for 3D analyses of soil in unit cell, (a) nodes and integration points for a C3D8P element; (b) mesh discretization. 
Table 1 Selected soil parameters for Bangkok soft clay (adopted from Indraratna et al., 2005b)

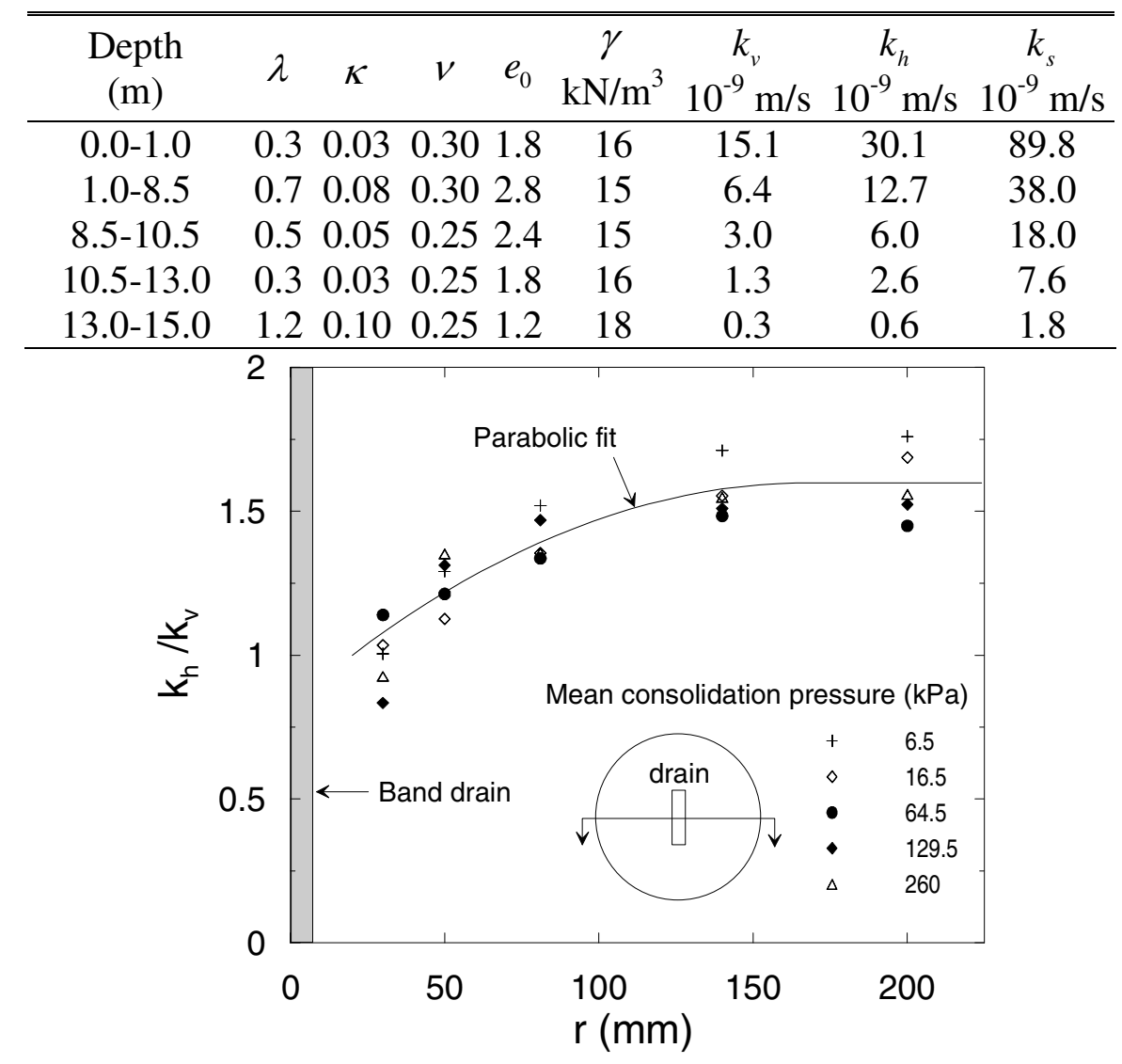

Figure 4 Parabolic distribution of permeability in the smear zone for Moruya clay (Walker and Indraratna, 2006)

In each embankment, a vacuum pressure up to $525 \mathrm{mmHg}(70 \mathrm{kPa})$ was applied using the vacuum pump. This pressure is equivalent to a fill height of $4 \mathrm{~m}$. After 45 days of vacuum application, the surcharge load was applied in 4 stages upto $2.5 \mathrm{~m}$ high with the unit weight of surcharge fill of $18 \mathrm{kN} / \mathrm{m}^{3}$ as illustrated in Fig. 5. Pore water pressures measured every $3 \mathrm{~m}$ deep by the electrical piezometers installed $0.5 \mathrm{~m}$ away from the centerline are shown Fig. 6a (AIT, 1995). After 40 days, a discrepancy was noted and attributed to the loss of suction head in the field due to an air leak from the membrane (Indraratna et al., 2004). Therefore, the magnitude of applied vacuum pressure at the surface and the top of the drains need to be adjusted, based on the field observations (Fig. 6b). It is assumed the vacuum pressure losses along the drain length linearly from the soil surface and becomes zero at the bottom of the drain. 


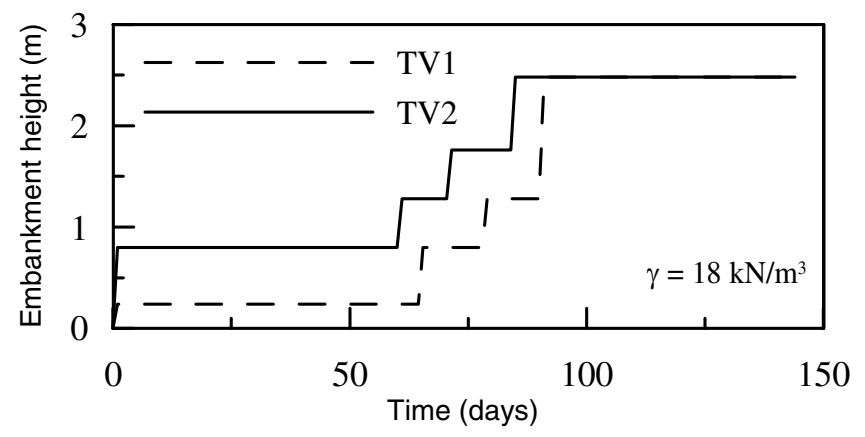

Figure 5 Multi-stage loading for embankments TV1 and TV2 (Indraratna et al. 2005b)

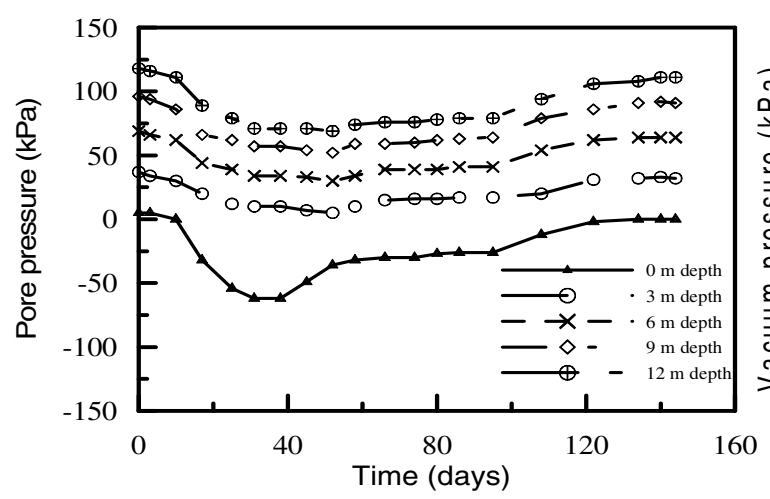

(a)

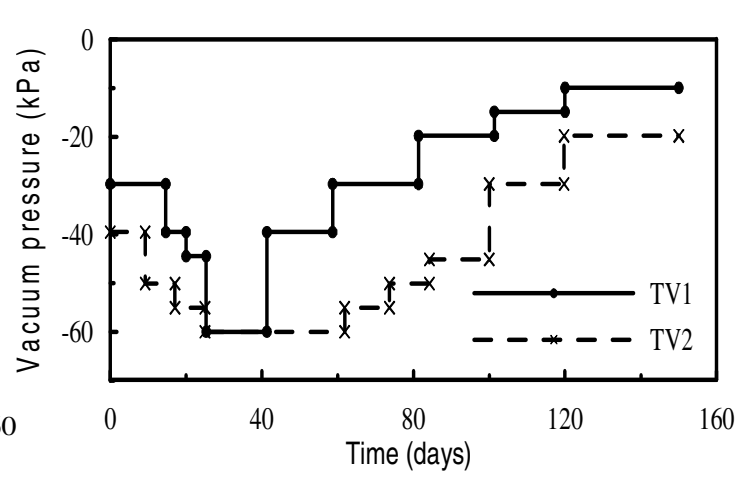

(b)

Figure 6 (a) Measured pore pressure at various depths and (b) Assumed pore pressure at the top soil surface in the FEM analysis (Indraratna et al. 2005b)

\section{ANALYSIS OF THE RESULTS}

Settlements: Based on a 3D single drain analysis, Figure 7 shows the comparison between the predicted surface centerline settlement and the measured data at various depths. The predicted results based on the assumptions provided by Indraratna et al. (2005b) agree well with the measured results except the predictions at the $9 \mathrm{~m}$ deep. 


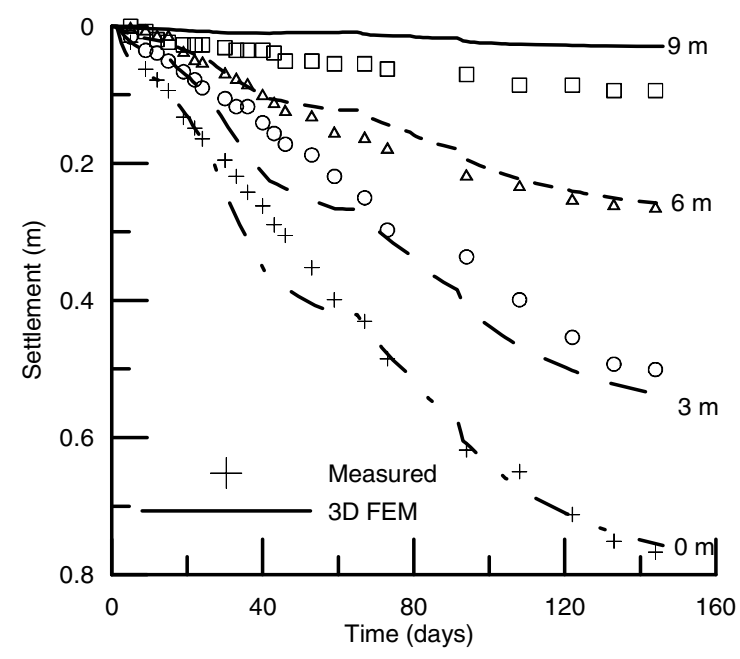

(a)

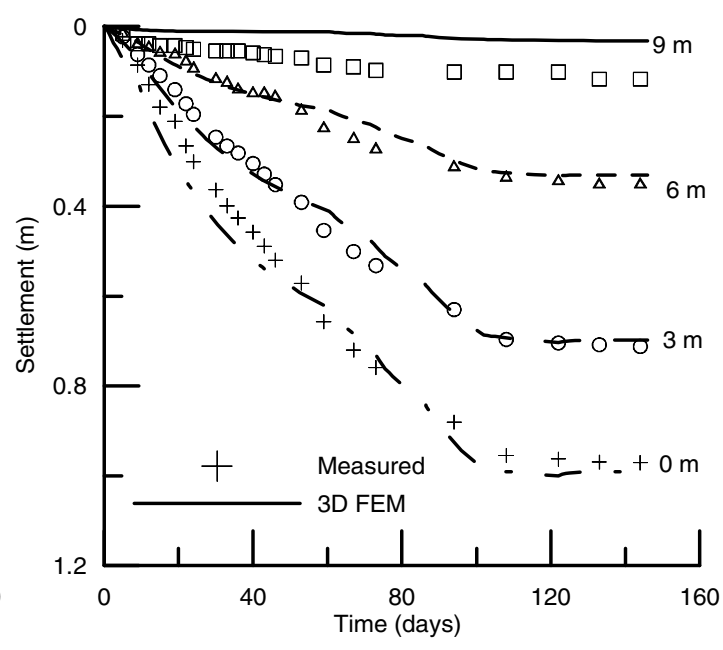

(b)

Figure 7 Consolidation settlement of embankment (a) TV1 and (b) TV2

Excess Pore Pressures: The predicted and measured excess pore pressures for embankments TV1 and TV2 are shown in Fig. 8. They suggest that the proposed assumption of linearly decreasing vacuum pressure along the drain length is justified. For Embankment TV1, the prediction underestimate the field measurment in the first 30 days. This may be due to the effect of drain unstauration delaying the propagation of vacuum pressure. Excess pore pressure responses from the vacuum application is significantly less than the conventional case, which enables increase the rate of construction of a vacuum-assisted embankment to be higher than conventional construction.

Comparison with Equivalent Plane Strain Results. Indraratna et al. (2005b) used the 2D equivalent plane strain FEM analysis for these case histories. Figure 9 shows the comparisons between the results obtained from the 3D FEM and the 2D FEM based on the conversion procedure provided by Indraratna and Redana (2000). The results from both analyses are very similar. The equivalent 2-D plane strain solutions are as powerful as 3D solutions but better in computation efficiency. However, the 3D FEM can be used to model the actual embankment geometry and drain installation patterns without any conversion procedures. 


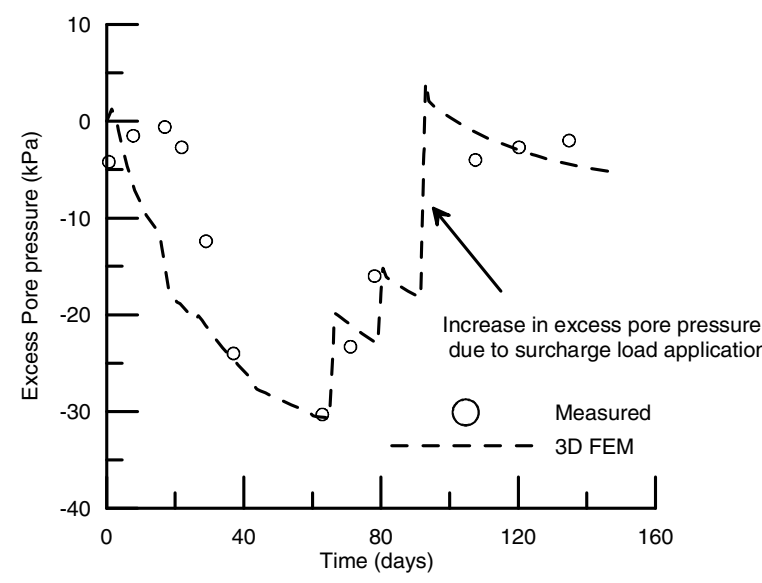

(a)

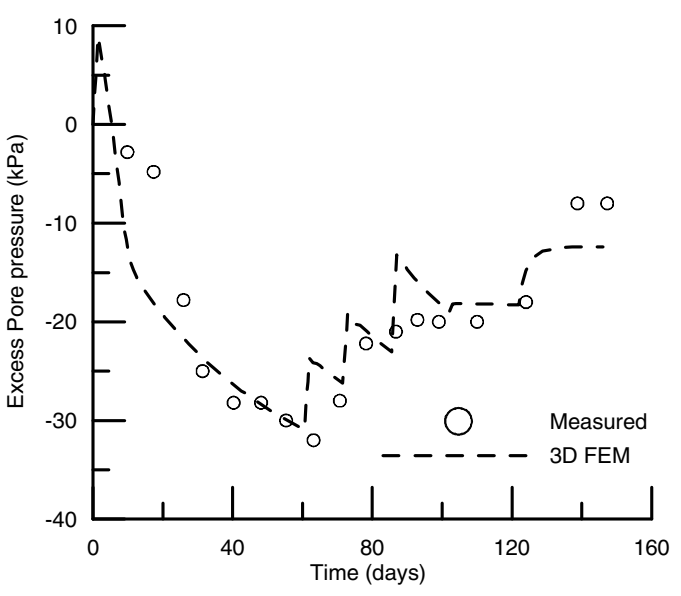

(b)

Figure 8. Variation of excess pore water pressure at $3 \mathrm{~m}$ below the surface and $0.5 \mathrm{~m}$ away from centreline (a) TV1 and (b) TV2
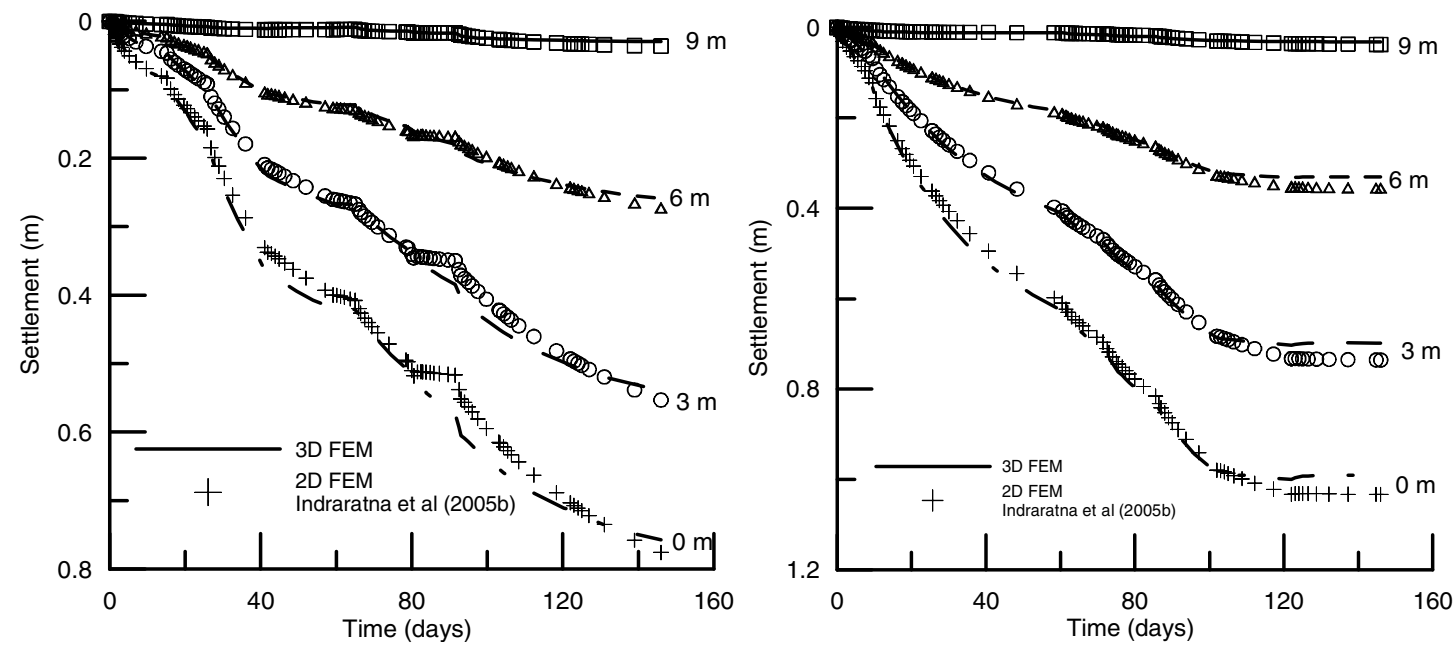

Figure 9. Variation of surface settlement at the embankment cemtre line (a) TV1 and (b) TV2

\section{CONCLUSIONS}

In this paper, a numerical model based on three-dimensional finite element method (FEM) was introduced to analyze two selected case histories at the Second 
Bangkok International Airport, Thailand improved by prefabricated vertical drains (PVDs) and vacuum preloading. The actual parabolic decay of soil permeability based on the large scale laboratory was incorporated in the analysis. The actual band PVD cross-section and its installation pattern were considered in the numerical simulation.

The predictions at the embankments' centerline from the FEM numerical model agree well with the field measurements such as settlements and excess pore pressures. It has been demonstrated that the actual time-dependent vacuum pressure and the vacuum pressure distribution along the drain length (i.e. linear distribution) play a very important role in predicting the settlement and excess pore pressure variations. In the vacuumassisted preloading, the actual excess pore pressure has to be carefully monitored to sustain the performance of the system. The predictions at the embankment centreline from 3D analysis are similar to those obtained from 2D FEM under the appropriate conversion approach. It is promising that 3D FEM can be used to simulate the actual vertical drain and embankment geometry as well as the drains installation pattern.

\section{REFERENCES}

Asian Institute of Technology, (1995). The Full Scale Field Test of Prefabricated Vertical Drains for The Second Bangkok International Airport (SBIA), Final Report. Div. of Geotech. \& Trans. Eng. AIT, Bangkok, Thailand, 259 p.

Barron, R. A. (1948). "Consolidation of fine-grained soils by drain wells." Transactions ASCE, 113(2346), 718-724.

Bo, M. W., Chu, J., Low, B. K., and Choa, V. (2003). Soil improvement; prefabricated vertical drain techniques, Thomson Learning, Singapore.

Borges, J.L. (2004). "Three-dimensional analysis of embankments on soft soils incorporating vertical drains by finite element method". Computers and Geotechnics. 31: 665-676.

Hansbo, S. (1981). "Consolidation of fine-grained soils by prefabricated drains." Proc. $10^{\text {th }}$ Int. Conf. SMFE., Stokholm, 677-682.

Hibbitt, Karlsson and Sorensen (2004). ABAQUS/Standard User's Manual, Published by HKS Inc.

Hird, C.C. and Moseley, V.J. (2000). "Model study of seepage in smear zones around vertical drains in layered soil". Geotechnique 50(1), 89-97.

Indraratna B., and Chu J. (2005). Ground Improvement - Case Histories Book (Volume 3), Elsevier, London 1115p.

Indraratna, B. and Redana, I. W. (1998). Laboratory determination of smear zone due to vertical drain installation." J. Geotech. and Geoenviron. Engng. 124(2): 180-185. 
Indraratna, B., and Redana, I. W. (2000). "Numerical modeling of vertical drains with smear and well resistance installed in soft clay." Canadian Geotechnical Journal, 37, 132-145.

Indraratna, B., Bamunawita, C., and Khabbaz, H. (2004). "Numerical modeling of vacuum preloading and field applications." Canadian Geotechnical Journal, 41, 1098-1110.

Indraratna, B., Rujikiatkamjorn C., and Sathananthan, I. (2005). Analytical and numerical solutions for a single vertical drain including the effects of vacuum preloading. Canadian Geotechnical Journal, 42, 994-1014.

Indraratna, B., Sathananthan, I., Rujikiatkamjorn C. and Balasubramaniam, A. S. (2005b). "Analytical and numerical modelling of soft soil stabilized by PVD incorporating vacuum preloading”. International Journal of Geomechanics, 5(2), 114-124.

Onoue, A., Ting, N.-H., Germaine, J. T. and Whitman, R. V. (1991). "Permeability of disturbed zone around vertical drains". Proc. ASCE Geotech. Engng. Congress. 2, 879-890.

Sangmala, S., (1997). "Efficiency of drainage systems of vacuum preloading with surcharge on PVD improved soft Bangkok clay," ME Thesis, Asian Institute of Technology, Bangkok, Thailand.

Sathananthan, I. and Indraratna, B. (2006). "Laboratory Evaluation of Smear Zone and Correlation between Permeability and Moisture Content. Journal of Geotechnical and Geoenvironmental Engineering”, ASCE, 132(7), 942-945.

Shang, J. Q., Tang, M., and Miao, Z. (1998). "Vacuum preloading consolidation of reclaimed land: a case study." Canadian Geotechnical Journal, 35, 740-749.

Sharma, J. S. and Xiao, D. (2000). Characterization of a smear zone around vertical drains by large-scale laboratory tests. Can. Geotech. J. 37(6): 1265-1271.

Walker, R. and Indraratna, B. (2006). "Vertical drain consolidation with parabolic distribution of permeability in smear zone". J. of Geotechnical \& Geoenvironmental Engineering, ASCE, 132(7), 937-941. 